\title{
YOUNG LEARNERS' RESPONSES ON THE USE OF ANIMATION IN AN ENGLISH CLASS
}

\author{
Ruruh Mindari (ruruhmindari@yahoo.com), M.J. Kriesye \\ Sriemulyaningsih (icecat762002@yahoo.com), Andrew Joewono \\ (andrew_sby@yahoo.com) ${ }^{10}$
}

\begin{abstract}
In an attempt to arouse young learners' interest and active participations in learning English in this digital era, a prototype of speaking material for primary school students has been developed. The material developed is a computer-based interactive module for primary school students. Designed in the form of animation featuring animal characters, the themes were presented in dialogues as well as brief introductory narrations whereas the speaking activities were designed based on language chunks accompanied with pronunciation practice. To find out young learners' reactions on the use of the materials developed, some try outs were conducted in some English classes of young learners. From the try outs it was found out that the young learners' responses varied. Some seemed interested but shy to participate, some participated with encouragements, and some others participated actively without encouragements. However, the overall perceptions of the young learners on the use of the digital materials showed their interest and enthusiasm. In terms of the quality of the materials, some aspects that needed improvements were the age of the voice actors, the operational buttons, and the variations of the interactive activities.
\end{abstract}

Key words: young learners, perceptions, animation

${ }^{10}$ Lectures of Widya Mandala Catholic University, Surabaya 


\section{Introduction}

Young learners nowadays are children of digital era. Since they were born, they have been familiar with gadgets. Babies are accustomed to watch DVDs or certain TV programs designed for them while being fed. Toddlers play with digital toys and even walk in shoes equipped with digital accessories. Moreover when they grow older and go to school they will be involved more with technology in the learning process. They are accustomed to being exposed to audio and visualization, which play a big role in their sensory motor and cognitive development as well.

Meanwhile, the young learners should be equipped in such a way that they will be more prepared to face the competitive world. Besides exploring and developing their competences, providing them with an English communication skill is becoming vital now. As we know, there are still many students as well as adults in Indonesia who are struggling in English communication. They generally understand what someone is talking about but they cannot express their ideas or feelings in English. This weakness may hinder them from their maximum development of potential and career.

In the effort of helping young learners to learn to speak English and at the same time to adjust the teaching technique to young learners' characteristics as well as their way of life nowadays, a computer-based interactive module has been developed in the previous research. Designed in the form of animation featuring animal characters, the themes were presented in dialogues as well as introductory narrations whereas the speaking activities were designed based on language chunks accompanied with pronunciation practice.

\section{General Characteristics of Young Learners}

In teaching English to young learners, it is essential that teachers know the characteristics of children. The knowledge of their specific characteristics helps teachers in planning the lesson, choosing the suitable 
techniques and designing the activities as well so that the learning is effective. By nature children have their own characteristics. The following points are children's common characteristics set forth by some experts:

- They live in the imagination world (Halliwell, 1992; Slattery \& Willis, 2001).

- They like to play and learn maximally when doing enjoyable activities (Halliwell, 1992; Slattery \& Willis, 2001, Scott \&Ytreberg, 2004).

- They can learn something indirectly (indirect learning) through activities which is also called learning by doing.

- $\quad$ They have a big curiosity (Perry, 2001)

\section{(http://teacher.scholastic.com/professional/bruceperry/curiosity.htm)}

- They will learn more effectively if the information input involves more than one sense (http://everydaylife.globalpost.com/senses-involvedchilds-cognitive-development-2638.html)

- Meanwhile, Brewster (2007) argues that children tend to be self oriented and busy with themselves, able to imitate something very well, and get bored easily. However, if attracted in something, they can concentrate for a long time.

\section{The Role of Audio-visual Aids in ELT}

Allou (2013), a post graduate student in Turkey, conducted a study entitled The Effect of Audiovisual Aids in Teaching Speaking Skill among EFL Learners. As the author defines, audio-visual aids are teaching aids from which learners are able to grasp directly the meaning and content of what is seen and heard through the visual and auditory senses. Further the author gives the examples of audio-visual such as motion picture, audio or video tape, slide or filmstrip, which is prepared to communicate information or to elicit a desired audience response. Those products make learning activities enjoyable and motivating carried on through the sense of hearing or sight. Some advantages of using audio -visual aids in language learning mentioned by the author are as follows: 
(1) It help the students in understanding languages by making him in direct contact with objects and things that is to say to create realistic world

(2) It helps students understand different cultural background

(3) Audio-visual aids promote remembering by involving the many senses of the learners, by arousing their curiosity, by making use of pictorial content and by providing variety in teaching.

(4) They make teaching effective by creating situations for presentation and practice of language items and by reducing dependence on the mother tongue.

(5) They help in formation of language habits by drill, repetition and constant practice.

In addition to the benefits mentioned above, Harmer (2001) as cited in Meriem (2014) sets forth that video can give to the language learners something beyond the common learning experience, such as seeing language in use and cross-cultural awareness.

Meanwhile, Arikan (2010) investigated the effectiveness of authentic animated cartoon series "The Simpsons" in teaching grammar and vocabulary to young Turkish learners of English compared to traditional teaching sessions in a primary school setting. The results indicate that although at the beginning of the study both the experimental and the control group performed poorly in the test, at the end of the study the experimental group outperformed the control group.

\section{Principles of Teaching English to Young Learners}

To meet the natural characteristics of children, experts on English for Young Learners suggest the principles of teaching English to young learners. The following principles are suggested by McCloskey (2002):

- Children should be given active and enjoyable roles in learning experience.

- Children should be supported to develop and practice language through collaborations. 
- Multi-dimensional thematic activities should be used in order that they learn English expressively and they have an understanding that is more reinforced by those various activities in the theme.

- Comprehensible input is given by giving assistance so that children can reach a higher achievement.

- Language that is integrated with the content makes them learn meaningfully so that they have better comprehension and a longer retention.

- The mother tongue should be strengthened and integrated with the culture.

- Clear objectives must be decided to direct the learning process, while the inputs for the children's performance will increase their language skills.

\section{Social-interactionist View}

Some psychology streams view the relation between the process of first language acquisition and that of foreign language. One of them is social-interactionist stream that emphasizes the importance of interaction in language teaching process. To introduce the idea, Vygotsky in the thirties proposed Zone of Proximal Development (ZPD). He believed that in learning something, children will be able to reach a higher achievement with the help of someone who is more knowledgeable. Holding this as the principle, teachers can help and at the same time give challenge to their students through well planned assignments. This idea was supported by Brunner (1938) who showed that without the help of an adult, or scaffolding, LAD cannot function maximally.

\section{Research Question}

This mini study is the follow up of the previous one, which was developing a computer-based interactive module as speaking materials for 
primary school students. It aims at answering the research question "What are young learners' perceptions on the use of animation in an English class?

\section{Research Objective}

The objective of the study is to find out young learners' perceptions on the use of animation in an English class.

\section{Research Significance}

By knowing young learners' perceptions on the use of animation in an English class, the strengths and weaknesses of the teaching media are found out and based on the detailed information, some follow up improvements can be done to make it more effective for teaching English to young learners.

\section{Research Method}

This qualitative study is a survey which was conducted in two groups of young learners' classes consisting of 22 students aged 7 to 10 . As the technique of teaching using animation was new for the participants, it was played twice before moving on to the activities. Two sets of Likert scale questionnaires were used to elicit the data from the participants after the interactive activities had finished. The first questionnaires consisted of questions about their' perceptions on the physical appearance of the animation, while the second one were more on the influence of animation on the learners.

\section{The Format of Learning Activities}

There are some format designs for computer-based English modules, however, in this study, the format used is the one that encourages the users to speak English. It starts with a short narration to introduce the topic that it is followed by a dialogue that uses certain language chunks. The language chunks are imitated by the learners in a pronunciation 
exercise. In the next step, the learners interact in small groups using the expressions they have heard and imitated. From the experience of interacting with the characters in the module, the learners are expected to use the expressions with their peers in their daily social activities.

\section{Findings and Discussion}

The results of questionnaires $\mathrm{A}$, which is about the physical appearance of the animation showed the following perceptions:

More than half of the subjects (63.63\%) said that the characters' appearance was very interesting, some said interesting (27.27\%), and two participants $(9.09 \%)$ said slightly interesting. About the voice of the characters, half of the participants (54.54\%) said it was interesting, some said very interesting (36.36\%) and two of them $(9.09 \%)$ said slightly interesting. When it came to the movements of the characters, ten participants $(45,45 \%)$ said it was very interesting, two participants $(9.09 \%)$ said interesting, $18.18 \%$ said it was not interesting, and $9.09 \%$ said not interesting at all. In responding to the interactive activities, $45.45 \%$ said very interesting, $18.18 \%$ said interesting, $27.27 \%$ said slightly interesting, and $9.09 \%$ said they were not interesting at all. In commenting on the colors of the animation, $63.63 \%$ said they were very interesting. Meanwhile, $18.18 \%$ said the colors were interesting, $9.09 \%$ said slightly interesting, and the rest, 9.09 said they were not interesting at all. About the accompanying music $36.36 \%$ said it was very interesting and $27.27 \%$ said interesting. Another $27.27 \%$ said it was not interesting, and $9.09 \%$ said it was slightly interesting.

From the data above it was found the average response of each aspect of the physical appearance of the animation as follows:

Table 1 Responses on the physical appearance of the animation

\begin{tabular}{|l|l|c|}
\hline No. & Aspect & Average \\
\hline 1 & Characters' appearance & 4.34 \\
\hline
\end{tabular}




\begin{tabular}{|l|l|c|}
\hline No. & \multicolumn{1}{|c|}{ Aspect } & Average \\
\hline 2 & Voice & 4.27 \\
\hline 3 & Movements & 3.63 \\
\hline 4 & Activities & 3.90 \\
\hline 5 & Colors & 4.27 \\
\hline 6 & Music & 3.72 \\
\hline
\end{tabular}

\section{Responses on the physical appearance of the} animation



Questionnaires B was about the influence of the animation on the participants or what the participants felt while learning English using animation. The results are as follows. On the question whether they wanted to try speaking in English, $72.72 \%$ of the participants stated they absolutely agreed and $27.27 \%$ agreed. Upon the question if the animation increases their courage to speak English $45.45 \%$ absolutely agreed. The same amount, $45.45 \%$ agreed, and $9.09 \%$ slightly agreed. In responding to the question if the animation made them like English more, $63.63 \%$ absolutely 
agreed, $27.27 \%$ agreed, and $9.09 \%$ slightly agreed. Further, most of the participants absolutely agreed that the animation made it easier for them to understand English conversations, $18.18 \%$ agreed, and $9.09 \%$ did not agree at all. Finally $63.63 \%$ of the participants absolutely agreed and the rest agreed that the animation made them enjoy the English learning process.

Table 2 The influence of the animation on the young learners

\begin{tabular}{|l|l|c|}
\hline No. & Aspect & Average \\
\hline 1 & Motivation to speak English & 4.72 \\
\hline 2 & Courage & 4.36 \\
\hline 3 & Interest & 4.54 \\
\hline 4 & Facilitating comprehension & 4.45 \\
\hline 5 & Enjoyment & 4.63 \\
\hline
\end{tabular}

\section{The influence of the animation on the young} learners

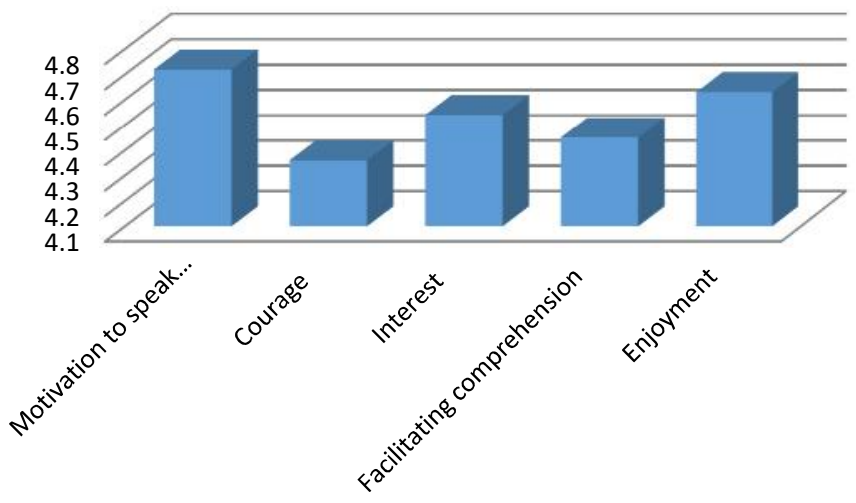

Average Responses

The findings revealed in the study confirm how authentic animated cartoon might contribute to certain extent in terms of encouraging young learners to try speaking the target language. As Krashen (1988) 
claims in his Affective Filter hypothesis that learners with high motivation, self-confidence, a good self-image, and a low level of anxiety are better equipped for success in second language acquisition. One of the ways to create a low level of anxiety is by providing a relaxing atmosphere which is free of tension for their learning process. The respective animation used aided to create a comforting class atmosphere.

One of the encouraging factors known to suit the young learners' characteristics is the integration of moving pictures, in the form of animation. Animation that is particularly interactive-applying the language of real-life conversation-can provide learners with this real-life language input, always in a motivating and interesting way. It is when animation has its contribution to make learning process more entertaining and enjoyable for the students in the elementary level.

However, other factors seem to have influenced the students' enthusiasm in using English as their target language: the encouragement of the teacher. Having watched the animation, the students need guided discussion and stimulus delivered by the teacher when they get a chance to really utter the language chunks found in the previous animation. A teacher who is active, engaging, and able to apply the language model to the students in class certainly boosts the students' enthusiasm.

\section{Conclusion}

Besides having some characteristics like curious, getting bored easily, and living in the imaginative world, young learners nowadays are also accustomed to watching audio visual entertainments. As can be seen in the findings, in general, they have positive perceptions on the use of animation in their English class. They liked the appearance of the animal characters in the animation and more importantly, it made them enjoy the learning process, helped them in understanding the dialogues, and encouraged them to speak English. As they enjoy the learning activity, their mind is stress-free and in such a condition, they can learn optimally. The 
use of animation, therefore, is recommended for teaching English to young learners.

\section{References}

Allou (2013). The Effect of Audiovisual Aids in Teaching Speaking Skill among EFL

Learners. (Online) http://dspace.univbiskra.dz:8080/jspui/bitstream/123456789/4809/1/The\%20Effect $\%$ 20of\%20Audiovisual\%20Aids\%20in\%20Teaching\%20Speaki ng\%20Skill.pdf

Arikan, A. (2010). Contextualizing young learners' English lessons with cartoons:

Focus on Grammar and Vocabulary. Procedia-Social and Behavioral Sciences. Volume 2, Issue 2, $2010 . \quad$ (Online) http://www.sciencedirect.com/science/article/pii/S187704281000 8888

Brewster, Jean cs. 2007. The Primary English Teacher's Guide. Edinburg Gate: Pearson Education Limited

Bruner, J. 1983. Child's Talk: Learning to Use Language, New York: Norton

Halliwell, S. 1992. 1992. Teaching English in the Primary Classroom. Harlow: Longman.

Harmer, J. 2010. The Practice of English Language Teaching. Essex: Longman (Online) http://www.worldcat.org/title/practice-ofenglish-language-teaching/oclc/46591508

Krashen, Stephen D. Second Language Acquisition and Second Language Learning. Prentice-Hall International, 1988. 
McCloskey, ML. 2002. Seven Instructional Principles for Teaching Young Learners of English. www.mlmcc.info.

Perry, B.D. 2001. Emotional Development: Curiosity-The Fuel of Development. Early Childhood Today: March, 2001 issue.

Scott, WA \& Ytreberg, LH. 1994. Teaching English to Children. New York: Longman

Slattery, M. \& Willis, J. 2001. English for Primary Teachers. Oxford: Oxford University Press. 